Published in final edited form as:

Methods Enzymol. 2002 ; 343: 578-600.

\title{
Rhodopsin and Its Kinase
}

\author{
Izabela Sokal, Alexander Pulvermüller, Janina Buczyłko, Klaus-Peter Hofmann, and \\ Krzysztof Palczewski
}

\section{Introduction}

In photoreceptor cells of the vertebrate retina, the light-sensitive chromophore, 11-cis-retinal, is linked covalently to receptor molecules. In rod cells, absorption of a photon causes photoisomerization of 11-cis-retinal to all-trans-retinal, triggering conformational changes in rhodopsin (Rho). Photolyzed Rho (Rho*) binds and activates G proteins; in turn, activated G proteins initiate subsequent biochemical steps that lead to a decrease in [cGMP] and consequently permeability of cyclic-GMP-gated cation channels in the photoreceptor plasma membrane. Similar reactions are initiated by conformational changes in receptor molecules of cones. In order for the signaling state of photoreceptors to return to the dark condition, Rho* and activated G proteins are turned off and cGMP is resynthesized. Phosphorylation of Rho* and binding of the capping protein arrestin (Arr), result in the termination of physiological responses (Fig. 1). While Rho* must be turned off to prevent continued activation of the entire population of $\mathrm{G}$ protein, its phosphorylation and subsequent Arr quenching must be timed properly in order for a given number of G protein molecules to become activated by Rho*. All of these activation and quenching reactions occur within hundreds of milliseconds and are collectively termed phototransduction. ${ }^{1-3}$

Many advances made in the elucidation of molecular details of phototransduction have paved the way for the rapid progress made in understanding of other $\mathrm{G}$ protein-coupled receptor (GPCR) systems. Thus, phototransduction is a prototypical model of the signal transduction initiated by other GPCR.

\section{Rho* Cycle of Activation, Termination of Activity, and Regeneration of Dark State}

Rho exists in an inactive conformation, which upon absorption of light is converted to an active form, Rho* (Fig. 1). The activation persists for a short time (milliseconds), allowing Rho* to catalyze nucleotide exchange (from GDP to GTP) on a fraction of the G protein pool. The amplification gain for a single Rho* is the activation of several hundred $\mathrm{G}_{\mathrm{t}}$ (transducin) protein molecules. Like $\mathrm{G}_{\mathrm{t}}$, rhodopsin kinase (RK, GRK1) also binds to cytoplasmic loops of Rho*, forming a stable complex, ${ }^{4}$ and then Rho* is phosphorylated at the $\mathrm{C}$ terminus.

Phosphorylation may have a small inhibitory effect on $G$ protein activation, but for some receptors, phosphorylation may reduce the activity by as much as $80 \% .{ }^{5}$ Rho* phosphorylation causes an $\sim 50 \%$ decrease in $\mathrm{G}_{\mathrm{t}}$ binding. ${ }^{6}$ In vitro, GPCRs*, including Rho*, were reported to be phosphorylated to a high stoichiometry of seven to nine phosphates per receptor. However, a single phosphate per receptor, as observed in vivo, ${ }^{7}$ is sufficient for quenching Rho* activation. ${ }^{8}$ The affinity of RK for Rho* is weakened by autophosphorylation, allowing RK to dissociate. Next, the regulatory protein Arr, binds to phosphorylated Rho*. In the Rho*$\mathrm{P}_{\mathrm{i}}$ - Arr complex, Rho* is unable to interact with the G protein. Formation of the GPCR*-P $\mathrm{P}_{\mathrm{i}}$. Arr complex could be a fast process that results in lowering the effective receptor concentration capable of interacting with $\mathrm{G}$ proteins. In vision, this role of Arr is implausible because the Rho concentration is very high, $\sim 3 \mathrm{~m} M$. It has been proposed that Rho* could also be quenched by phosphorylation-independent mechanisms that involve $\mathrm{p}^{44}$, a splice form of Arr ${ }^{9-11}$ (Fig. $1)$. 
For Rho*, removal of the agonist by reduction of all-trans-retinal to all-trans-retinol leads to the release of Arr and dephosphorylation of the receptor by a membrane-associated form of protein phosphatase $2 \mathrm{~A}$ (PP2A). ${ }^{12,}{ }^{13}$ Rho is fully regenerated when a new 11-cis-retinal binds to opsin.

\section{G Protein Receptor-Kinases (GRKs)}

Termination of GPCR signaling by phosphorylation is a well-established phenomenon that involves two types of Ser/Thr protein kinases: G protein-receptor kinases (GRKs) (EC 2.7.1-) and kinases activated by second messengers (e.g., protein kinase A or protein kinase C). Several comprehensive reviews concerning different aspects of receptor phosphorylation have been published. ${ }^{14-21}$

Seven members of related mammalian GRKs have been characterized (Fig. 1B). These enzymes are single-subunit (63-80 kDa), water-soluble proteins, with 30-85\% amino acid sequence identity between protein pairs (57-96\% overall similarity). GRK2, GRK3, and GRK6 are expressed ubiquitously, in contrast to the more specific localization of GRK1, GRK7 (retinal photoreceptor cells and pinealocytes), GRK4 (testis, brain), and GRK5 (heart, lung, and retina). The role of RK in photoreceptors is likely restricted to phototransduction, while its function in the pineal gland is unknown. 22

\section{Interaction between Rho* and Its Kinase}

Binding of ATP to $\mathrm{RK}^{23}$ increases the affinity for the activated receptor by a factor of $\sim 10$ $\left(\sim 10 \mu M^{-1} \mathrm{sec}^{-1}\right)$. In addition to a weak interaction of phosphorylated region within the catalytic site of RK, interaction between the kinase and the cytoplasmic surface of Rho* provides the stability for the complex. RK recognizes Rho*, or protonated opsin on acidic residues within $\alpha$-helical or cytoplasmic domains. ${ }^{24}$ The Rho*.RK complex involves the Nterminal domain of the kinase and cytoplasmic loops of the receptor. ${ }^{25}$ The $k_{\text {off }}$ for the Rho* RK complex is increased when either the kinase or the receptor is phosphorylated. ${ }^{23} \mathrm{~A}$ weak interaction between the $\mathrm{C}$ terminus of Rho* and the active site of RK promotes phosphorylation at different sites. Therefore, the Rho*.RK complex may produce several intermediates each with a unique catalytic site positioning of GRK toward the phosphorylation site. Rho* phosphorylation at different sites, including $\mathrm{Ser}^{334}$, $\mathrm{Ser}^{338}$, and $\mathrm{Ser}^{342}$, may play different roles in phototransduction.

The following section describes methods useful in the characterization of GRKs, in particular RK, including assays for enzymatic reactions and interaction with Rho* using spectroscopic methods, isolation, expression, and immunodetection. In addition, it provides short descriptions of methods and references helpful in the identification of phosphorylation sites.

\section{Experimental Procedures}

Preparations of rod outer segments (ROS) are the source of phototransduction enzymes, Rho, and opsin in native membranes.

i. ROS are prepared under dim red light at $5^{\circ}$ from fresh bovine retinas obtained locally or from frozen retinas (Schenk Packing Co., Inc.) employing a sucrose gradient procedure ${ }^{26}$ and are stored at $-80^{\circ}$. Rho, which is a main component of ROS ( 85\%), as judged by SDS-PAGE, is isolated in 100-mg quantities from bovine retinas ( $\sim 0.5 \mathrm{mg} / \mathrm{eye})$.

ii. For Rho* phosphorylation, to ensure the completeness of phosphorylation, ROS ( $\sim 2 \mathrm{mg}$ / $\mathrm{ml}$ ) are resuspended and homogenized with $0.1 M$ potassium phosphate, $\mathrm{pH}$ 7.5. At this concentration, phosphate strongly inhibits PP2A. 
iii. For preparation of Rho as RK substrate, soluble and membrane-associated proteins are removed. ROS are suspended at $1 \mathrm{mg}$ of Rho/ml in $5 M$ urea, $10 \mathrm{mM}$ BTP (1,3-bis[tris (hydroxymethyl)-methylamino]propane), $\mathrm{pH} 7.5$, at room temperature. ${ }^{27}$ Prolonged exposure to urea should be avoided due to potential denaturation of Rho. After $15 \mathrm{~min}$, ROS membranes are centrifuged and washed four times with $67 \mathrm{~m} M$ potassium phosphate, pH 7.5. Finally, ROS membranes $(3.6 \mathrm{mg} / \mathrm{ml})$ are suspended in $10 \mathrm{~m} M$ BTP, pH 7.5, containing $100 \mathrm{mM} \mathrm{NaCl}$ and $5 \mathrm{mM} \mathrm{MgCl}_{2}$.

iv. For preparation of opsin as RK substrate, urea-washed Rho is prepared. Opsin $(0.3 \mathrm{mg} / \mathrm{ml})$ is prepared from urea-washed Rho by thorough bleaching at $0^{\circ}$ (typically 15 min) with a 180 W lamp at a distance of $20 \mathrm{~cm}$ in $10 \mathrm{~m} M$ BTP, pH 7.5, containing $50 \mathrm{~m} M \mathrm{NaCl}$. Opsin is pelleted by centrifugation $(37,000 \mathrm{~g}, 20 \mathrm{~min})$, suspended in $10 \mathrm{mM}$ BTP, $\mathrm{pH} 7.5$, containing $50 \mathrm{mM} \mathrm{NaCl}$, and stored frozen at $-20^{\circ}$ in small aliquots at $3.6 \mathrm{mg} / \mathrm{ml}$. For routine assay of the activity, the removal of all-trans-retinal is not necessary. However, if the question is related to the efficiency of opsin activation, removal of all-trans-retinal, converted to the oximes, is necessary. In this case, bleaching should be carried out in the presence of $45 \mathrm{mM} \mathrm{NH} \mathrm{N}_{2} \mathrm{OH}$. The oximes of all-trans-retinal are extracted with petroleum ether $(10 \mathrm{ml} / 10 \mathrm{ml}$ of the opsin suspension). A brief centrifugation $(18,000 \mathrm{~g}, 10 \mathrm{~min})$ separates the organic and water layers, and the organic phase is discarded. The extraction is repeated four times. To facilitate opsin sedimentation, $\mathrm{NaCl}$ is added to the opsin suspension to a final concentration of $0.5 \mathrm{M}$ and centrifuged at 37,000 $\mathrm{g}$ for $35 \mathrm{~min}$. Opsin is suspended with $10 \mathrm{mM}$ BTP, pH 7.5, containing $50 \mathrm{~m} M \mathrm{NaCl}$.

\section{Assays of RK Activity}

RK activity is tested using four assays, individually or in combination. Assays measure phosphotransfer reaction from $\left[\gamma_{-}{ }^{32} \mathrm{P}\right] \mathrm{ATP}$ to (1) Rho*,27-30 (2) opsin activated by chromophore, all-trans-retinal, or analogs, ${ }^{24}$ (3) RK in autophosphorylation reaction, ${ }^{31}$ and (4) synthetic peptides derived from the C-terminal phosphorylation region of Rho, or other unrelated peptides. 28,32

i. RK specifically phosphorylates Rho* and has negligible activity toward Rho or opsin. RK activity in fractions of interest is measured using $50 \mu M\left[\gamma^{32} \mathrm{P}\right] \mathrm{ATP}(100-500 \mathrm{cpm} / \mathrm{pmol}$, DuPont NEN) and urea-washed ROS membranes ${ }^{33}$ containing $10 \mu M$ Rho in $20 \mathrm{mM}$ BTP, 1 $\mathrm{mM} \mathrm{MgCl} 2, \mathrm{pH} 7.5$, at $30^{\circ}$. The total volume is $200 \mu \mathrm{l}$ in a $1.5-\mathrm{ml}$ microcentrifuge tube. The reaction is initiated by light and carried out under a 150-W lamp from a distance of $20 \mathrm{~cm}$ for 5,10 , and $15 \mathrm{~min}$ in triplicates. No specific light requirements are critical. Typically, white light that bleaches $10 \% \mathrm{Rho} / \mathrm{min}$, as determined spectrophotometrically by the decrease in the absorption of Rho $(498 \mathrm{~nm}),{ }^{34}$ is used. The reaction is stopped by the addition of $10 \%$ $\mathrm{CCl}_{3} \mathrm{COOH}$, Rho-containing membranes are pelleted by low-speed centrifugation, and the excess $\left[\gamma_{-}{ }^{32} \mathrm{P}\right] \mathrm{ATP}$ is removed by repetitive three cycles of washes/centrifugations (Eppendorf centrifuge, Model 5415C, 2 min at maximal speed) with $1.5 \mathrm{ml}$ of $10 \% \mathrm{CCl}_{3} \mathrm{COOH}$. Finally, after $\left[\gamma^{-32} \mathrm{P}\right]$ ATP is removed, Rho is solubilized with $1 \mathrm{ml}$ of $96-100 \% \mathrm{HCOOH}$ and mixed with the scintillation cocktail for radioactivity counting. Lower concentrations of $\mathrm{HCOOH}$ may not dissolve all membranes or may take a long time (3-4 hr) for solublization. Routinely, a time course (Fig. 2A), RK dose dependence (Fig. 2B), and Rho* dose dependence should determine linear ranges and verify the accuracy of the assay. Typically, the specific activity is $100-700 \mathrm{nmol} \mathrm{P}_{\mathrm{i}}$ transfer per minute per $1 \mathrm{mg}$ of purified RK. Due to broad specificities of GRKs and availability of Rho as the receptor, similar assays are employed to monitor activities of all GRKs.

The phosphorylation reaction requires $\sim 1 \mathrm{mM} \mathrm{MgCl}$, whereas a higher concentration inhibits RK. ${ }^{29}$ Maximal RK activity is observed between $\mathrm{pH} 6.0$ and $\mathrm{pH} 8.0$, and salts up to 500 $\mathrm{m} M$ have little effect on the activity. ${ }^{29}$ Due to $\mathrm{Mg}^{2+}$ coordination, chelators inhibit RK activity. 
$\mathrm{Ca}^{2+}$ and cyclic nucleotides do not affect RK activity. ${ }^{29}$ Polycations activate RK (approximately twofold), whereas negatively charged polyanions inhibit RK. ${ }^{28}$ Nucleotide specificity has been tested extensively and resulted in the identification of substrates and potent nucleoside inhibitors. ${ }^{27,35,36}$ ATP is a preferential donor of the phosphate group, whereas GTP is a poor substrate.

ii. RK activity, and most likely other GRKs, could be tested conveniently using opsin activated by retinoids. ${ }^{24}$ Binding of retinoids to a distinct binding pocket causes changes in the opsin structure, converting this receptor from the inactive to the active conformation. This process is similar to the activation of other GPCRs by agonists. There is a specific structural requirement for retinoids for maximal activation. Commercially available all-trans-retinal is very potent in the activation. Shortening the polyene chain of retinoid leads to improvement of the activation efficiency, which is followed by a rapid decrease in activation. It appears that the binding pocket can be measured by a "molecular ruler," employing the aldehyde form of retinoids of different lengths, or extended by converting them to oximes (Fig. 3). The reaction does not require light and is steeply $\mathrm{pH}$ dependent with maximal activity at lower $\mathrm{pH}$. A practical $\mathrm{pH}$ for the assay is 5.5-6.0. ${ }^{24}$ The activity is only a fraction $(\sim 10 \%)$ of the activity obtained using fresh Rho*; however, the opsin/retinoid assay is highly reliable and easy to perform. The assay requires opsin and an ethanolic solution of all-trans-retinal (note that this compound is light, oxygen, and temperature sensitive and should be stored at $-80^{\circ}$ under argon). This assay is not applicable for RK fractions with low enzymatic activities. The specificity of retinoid-dependent activity is demonstrated by employing different lengths of retinoids (Fig. 3). This "molecular ruler" approach suggests that the optimal size of the binding site is for $\sim \mathrm{C} 17$-long retinoids. Because $\mathrm{C} 17$ does not regenerate Rho, these data together suggest that the binding site is different from the covalent binding of 11-cis-retinal, and likely involves a region around the palmitoylation groups on opsin. ${ }^{37}$

RK activity in fractions of interest is measured using $50 \mu M\left[\gamma_{-}{ }^{32} \mathrm{P}\right] \mathrm{ATP}(100-500 \mathrm{cpm} / \mathrm{pmol}$, DuPont NEN) and $10 \mu M$ opsin in $20 \mathrm{mM}$ BTP, pH 6.0, at $30^{\circ}$, containing $1 \mathrm{mM} \mathrm{MgCl} 2$. The total volume is $200 \mu \mathrm{l}$ in a $1.5-\mathrm{ml}$ microcentrifuge tube. The reaction is initiated by adding 2 $\mu \mathrm{l}$ of $10 \mathrm{mM}$ all-trans-retinal in $\mathrm{CH}_{3} \mathrm{CH}_{2} \mathrm{OH}$ and is carried out for 5,10 , and $15 \mathrm{~min}$ in triplicate. The reaction is stopped by the addition of $10 \% \mathrm{CCl}_{3} \mathrm{COOH}$, and the excess $\left[\gamma_{-}{ }^{32} \mathrm{P}\right] \mathrm{ATP}$ is removed by three cycles of washes/centrifugations (Eppendorf centrifuge, Model 5415C, 2 min at maximal speed) with $1.2 \mathrm{ml} 10 \% \mathrm{CCl}_{3} \mathrm{COOH}$. The samples are shaken using an Eppendorf shaker (mixer Model 5432) for 5 min between each wash in room temperature. Finally, Rho is solubilized with $1 \mathrm{ml}$ of $100 \% \mathrm{HCOOH}$ and mixed with the scintillation cocktail for radioactive counting.

iii. Active RK undergoes intramolecular autophosphorylation. ${ }^{31,38}$ The assay is not applicable when RK is prepared using ATP elution from the heparin column. Autophosphorylation is unaffected by the presence of Rho* or P-Rho*.

RK autophosphorylation in fractions of interest is measured using $50 \mu M\left[\gamma_{-}{ }^{32} \mathrm{P}\right] \mathrm{ATP}(1000$ $5000 \mathrm{cpm} / \mathrm{pmol}$, DuPont NEN) in $20 \mathrm{~m} M$ BTP, pH 7.5, at $30^{\circ}$, containing $1 \mathrm{~m} M \mathrm{MgCl}_{2}$. The total volume is $20 \mu \mathrm{l}$ in a $1.5-\mathrm{ml}$ microcentrifuge tube. The reaction is initiated by adding $\left[\gamma_{-}{ }^{32} \mathrm{P}\right] \mathrm{ATP}$ and is carried out for 5,10 , and $15 \mathrm{~min}$ in triplicate. The reaction is stopped with $5 \mu \mathrm{l}$ SDS-PAGE sample buffer. Excess $\left[\gamma-{ }^{32} \mathrm{P}\right] \mathrm{ATP}$ is separated by electrophoresis using $12 \%$ polyacrylamide gels. RK bands, identified by Western blotting, are cut out. The pieces of the gel are solubilized with $300 \mu \mathrm{l}$ of fresh $30 \% \mathrm{H}_{2} \mathrm{O}_{2}$ at $30^{\circ}$ (typically, this step requires $40-60$ min incubation) and mixed with the scintillation cocktail for radioactive counting.

iv. RK has low but measurable activity toward peptides corresponding to the phosphorylation region of Rho or unrelated acid peptides containing Ser or Thr residues. ${ }^{29,32}$ Phosphorylation 
of peptides at $\mathrm{pH} 8.5$ is three to four times faster than at $\mathrm{pH}$ 6.0. $\mathrm{RK}$ preferred acidic residues localize to the carboxyl-terminal side of the Ser residue, whereas other GRKs showed preference for acidic residues at the $\mathrm{N}$ terminus of the phosphorylation sites. RK has a much greater $K_{\mathrm{M}}$ for peptide substrates compared to that for intact receptor substrates, suggesting that interactions with Rho* are needed for maximal activity. $4,38-40$

RK activity in fractions of interest is measured using $50 \mu M\left[\gamma_{-}{ }^{32} \mathrm{P}\right] \mathrm{ATP}(500-800 \mathrm{cpm} / \mathrm{pmol}$, DuPont NEN) in $20 \mathrm{~m} M \mathrm{BTP}, \mathrm{pH} 8.5$, at $30^{\circ}$, containing $1 \mathrm{~m} M \mathrm{MgCl}_{2}$, and $1 \mathrm{~m} M$ peptide (e.g., the 327-348 peptide fragment corresponding to bovine Rho). The total volume is 200 $\mu \mathrm{l}$ in a $1.5-\mathrm{ml}$ microcentrifuge tube. The reaction is initiated by the addition of $\left[\gamma_{-}{ }^{32} \mathrm{P}\right] \mathrm{ATP}$ and is carried out for 30,60, and $90 \mathrm{~min}$ in triplicates. The reaction is stopped with $1 \% \mathrm{CF}_{3} \mathrm{COOH}$ $(100 \mu \mathrm{l})$, and the excess $\left[\gamma^{3}{ }^{32} \mathrm{P}\right] \mathrm{ATP}$ is removed by separation of the peptide on a $\mathrm{C} 18$ column (Vydac, $2.2 \times 25 \mathrm{~cm}$ ) using a $0-40 \%$ gradient of $\mathrm{CH}_{3} \mathrm{CN}$ containing $1 \% \mathrm{H}_{3} \mathrm{PO}_{4}$. The peptide is collected and mixed with the scintillation cocktail for radioactivity determination.

Alternatively, the peptide could be engineered to contain three Arg residues at the $\mathrm{N}$ terminus to tightly bind to P-cellulose. ${ }^{32}$ After reaction, excess $\left[\gamma_{-}{ }^{32} \mathrm{P}\right] \mathrm{ATP}$ is washed out from the peptide using P-cellulose paper in $75 \mathrm{mM} \mathrm{H}_{3} \mathrm{PO}_{4} \cdot{ }^{32}$

Phosphorylation of exogenous peptide is stimulated by the presence of catalytic amounts of Rho*, or its truncated forms. ${ }^{39,40}$ The half-maximal effect is observed at 5-15 $\mu M$ Rho*. 40 The efficiency of the peptide phosphorylation, as measured by $V_{\max } / K_{\mathrm{M}}$, increases maximally $\sim 150$ times in the presence of Rho*.

\section{Isolation of RK}

RK can be purified from native sources or from an expression system using several methods.

i. A combination of classical column chromatographies led to the isolation of highly purified RK. ${ }^{27}$ Next, tryptic fragments were obtained and RK cDNA was cloned. ${ }^{41}$ This method results in purified RK, but is labor-intense with a low yield.

ii. Efficient methods have been developed using the fact that RK undergoes rapid autophosphorylation (Fig. 4A), which changes the RK affinity for heparin 30,31,42-44 (Fig. 4B). Dephosphorylated RK can be extracted from $\operatorname{ROS}^{30,31}$ or retina 43 and loaded on to the heparin-Sepharose column. Contaminated proteins are washed off, and ATP/ $\mathrm{Mg}^{2+}$ is added onto the column to allow RK autophosphorylation. Phosphorylated RK specifically elutes from the column. Critical parameters are precise salt concentrations and the presence of $\mathrm{Mg}^{2+}$ in the autophosphorylation reaction on the column. This method and its variations for expressed RK, have been described previously. ${ }^{44}$ They are used widely by other laboratories.

\section{Purification of RK from Bovine Retina}

$\mathrm{RK}$ is purified from bovine retinas according to a modified procedure for RK purification from ROS. All procedures are performed at $4^{\circ}$. To remove soluble proteins that do not interact with Rho, 100 bovine retinas are homogenized in $20 \mathrm{~m} M$ BTP, pH 7.5, containing $5 \mathrm{mM} \mathrm{MgCl} 2$ and $1 \mathrm{~m} M$ benzamidine in a Dounce homogenizer with a motor-driven Teflon pestle $(20 \mathrm{ml} /$ 100 retinas). The suspension is bleached on ice for 2 min under white light and then centrifuged at 37,000 (JA-20 rotor, Beckman) for $10 \mathrm{~min}$. The extraction of soluble contaminating proteins is repeated once more, without bleaching. $R K$ and $\mathrm{G}_{t}$ are bound to Rho*, while the majority of soluble proteins are removed. At this stage of purification, due to a high concentration of other protein kinases and phosphorylations, there is a high phosphorylation background unrelated to RK. Thus, it is imperative that control assays for RK activity are carried out in the dark to substract from light-dependent phosphorylation. Roughly $\sim 15 \%$ of RK is lost during this procedure, as determined by immunoblotting. 
To extract RK, the pellets are suspended in $25 \mathrm{ml}$ of $20 \mathrm{~m} M$ BTP, pH 7.5, containing $10 \mathrm{~m} M$ $\mathrm{NH}_{2} \mathrm{OH}, 1 \mathrm{~m} M$ EDTA, $240 \mathrm{~m} M \mathrm{KCl}, 1 \mathrm{~m} M$ benzamidine, and $0.4 \%$ Tween 80, and are then further bleached on ice for $10 \mathrm{~min}$ under bright white light $(150 \mathrm{~W}$ from a distance of $20 \mathrm{~cm}$ ). At this stage, $\mathrm{Rho}^{*}$ is inactivated by $\mathrm{NH}_{2} \mathrm{OH}$ by a mechanism that involves conversion of photolyzed chromophore all-trans-retinal to all-trans-retinal oximes. The sample is centrifuged at 37,000 $\mathrm{g}$ for $10 \mathrm{~min}$. Optionally, the membranes can be extracted for the second time under identical conditions. Multiple extractions may cause, however, a progressively higher extraction of contaminating proteins that are difficult to remove during the next stages of purification.

The extract containing RK is dialyzed against $20 \mathrm{~m} M$ BTP, pH 7.5, containing $0.4 \%$ Tween 80 , and $1 \mathrm{~m} M$ benzamidine overnight. During dialysis, endogenous PP2A dephosphorylates RK. The dialyzed extract is loaded onto $20 \mathrm{ml}$ of a DEAE-cellulose column equilibrated with $10 \mathrm{~m} M$ BTP, pH 7.5, containing $0.4 \%$ Tween 80 . The column is washed extensively (100 ml) with the same buffer, and RK is eluted with $100 \mathrm{mM} \mathrm{NaCl}$ in $10 \mathrm{mM}$ BTP, pH 7.5, containing $0.4 \%$ Tween 80 in a step gradient. Fractions with RK activity are diluted with an equal volume of $10 \mathrm{~m} M$ BTP and loaded on $5 \mathrm{ml}$ heparin-Sepharose (Pharmacia).

The column is washed with $10 \mathrm{~m} M$ BTP containing $0.4 \%$ Tween 80 until the $A_{280} \leq 0.01$ $(\sim 30 \mathrm{ml})$ at $4^{\circ}$. A linear gradient from 0 to $500 \mathrm{mM} \mathrm{KCl}$ in $10 \mathrm{mM} \mathrm{BTP}, \mathrm{pH} 7.5$, containing $0.4 \%$ Tween 80 over $40 \mathrm{~min}$ is developed at $1.0 \mathrm{ml} / \mathrm{min}$, and $40 \times 1-\mathrm{ml}$ fractions are collected. Fractions containing RK activity eluted at $350 \mathrm{mM} \mathrm{KCl}$ are combined and diluted two-fold with $20 \mathrm{~m} M$ BTP, $\mathrm{pH} 7.5$, containing $1 \mathrm{~m} M n$-dodecyl- $\beta$-р-maltoside, loaded onto a 5-ml heparin-Sepharose column, and washed with $10 \mathrm{mM}$ BTP containing $0.4 \%$ Tween 80 and 100 $\mathrm{m} M \mathrm{NaCl}$. After absorption decreases below $<0.01$ at $280 \mathrm{~nm}$, the column is equilibrated with $10 \mathrm{~m} M$ BTP, pH 7.5, containing $1 \mathrm{~m} M n$-dodecyl- $\beta$-d-maltoside, $80 \mathrm{~m} M \mathrm{NaCl}, 1 \mathrm{~m} M$ ATP, and $1 \mathrm{mM} \mathrm{MgCl} 2$ until ATP begins to elute and then the column is closed for $1 \mathrm{hr}$ to allow autophosphorylation. RK is eluted when the column is open again. RK activity-containing fractions are pooled and diluted three-fold for Q-Sepharose chromatography. After washing the column (Pharmacia HR 5/5) with $5 \mathrm{ml} 10 \mathrm{~m} M$ BTP, pH 7.5, containing $1 \mathrm{~m} M n$-dodecyl$\beta$-D-maltoside, RK is eluted with a salt gradient from 0 to $500 \mathrm{mM} \mathrm{NaCl}$ in the same buffer over $20 \mathrm{~min}$ at $0.5 \mathrm{ml} / \mathrm{min}$.

iii. RK is also enriched in fraction from the rat pineal gland using affinity chromatography on a peptide from the $\mathrm{C}$-terminal Rho. Due to weak interaction between the phosphorylable region of Rho and RK, the column capacity is low. 45

iv. RK has also been purified using recoverin-Sepharose affinity chromatography. 46

\section{Immunodetection of RK}

RK is detected by a panel of antibodies generated against unique regions of RK and against native purified bovine enzyme. Unfortunately, the polyclonal antibodies are no longer available. They were used successfully to identify the region of RK that is involved in the interaction with Rho* and to immunolocalize the enzyme to rod and cone photoreceptor cells. 25

High-quality monoclonal anti-RK antibodies are raised against partially purified human RK expressed in Escherichia coli. ${ }^{43,47}$ Two antibodies are characterized: the G8 antibody displays C-terminal specificity and reacts with bovine (two autophosphorylation forms) (Fig. 4C), human, and chicken RK, and the D11 antibody, which displays N-terminal specificity and reacts strongly only with human RK. The antibodies are useful for immunocytochemistry, immunoprecipitation, and immunoblotting and are available commercially from Santa Cruz Biotechnology, Inc., Santa Cruz, California. 


\section{Heterologous Expression of RK}

RK has been expressed successfully in heterologous systems, including insect cells and COS cells. RK is inactive when expressed in E. coli. The expression of RK in insect cells, in the presence of mevalonolactone, led to heterogeneous incorporations of C-5, C-10, C-15, and $\mathrm{C}-20$ isoprenyl moieties to the $\mathrm{C}$-terminal Cys residue through a thioether linkage. ${ }^{48}$ Methods to identify the prenyl group have been described, ${ }^{49}$ and detailed analysis of the effect of Cterminal modifications on RK activity has been reported. 50

i. Insect cell expression. The full-length StuI/BamHI fragment of $\mathrm{RK}^{41}$ (1847 bp) is subcloned into a baculovirus transfer vector, pVL 1393 (Pharmingen). pVL-RK ( $3 \mu \mathrm{g})$ and a helper virus carrying a lethal deletion $(0.5 \mu \mathrm{g})$ are cotransfected into insect Sf9 cells (Invitrogen) in a 60$\mathrm{mm}$ tissue culture dish using a BaculoGold (TM) transfection kit (Pharmingen). A single recombinant baculovirus plaque is amplified to produce a virus stock. Three $150-\mathrm{mm}$ plates containing a monolayer of High Five insect cells (Invitrogen) are infected with the recombinant virus. Cells are harvested $96 \mathrm{hr}$ after the infection, collected by centrifugation at $5000 \mathrm{rpm}$, and homogenized with $10 \mathrm{mM}$ BTP, $\mathrm{pH} 7.5$, containing $0.4 \%$ Tween 80 , and the suspension is loaded on a DEAE-cellulose column $(1 \times 10 \mathrm{~cm})$ equilibrated with the same buffer. The column is washed with $10 \mathrm{~m} M$ BTP, $\mathrm{pH} 7.5$, containing $0.4 \%$ Tween 80 , and $\mathrm{RK}$ is eluted with 100 $\mathrm{m} M \mathrm{NaCl}$ in the same buffer. Fractions containing RK activity are combined and mixed with $2 \mu \mathrm{g}$ of PP2A, dialyzed overnight against $10 \mathrm{mM}$ BTP, $\mathrm{pH} 7.5$, containing $0.4 \%$ Tween 80 and $1 \mathrm{~m} M$ benzamidine (1 liter), and loaded onto a heparin-Sepharose column $(1 \times 5 \mathrm{~cm})$ equilibrated with the same buffer. After the column is washed with $10 \mathrm{~m} M$ BTP, pH 7.5, containing $0.4 \%$ Tween $80,1 \mathrm{mM} \mathrm{MgCl} 2$, and $125 \mathrm{mM} \mathrm{NaCl}$, RK (>98\% pure, $300 \mu \mathrm{g}$ ) is eluted with ATP in $10 \mathrm{mM}$ BTP, $\mathrm{pH} 7.5$, containing $0.4 \%$ Tween $80,1 \mathrm{mM} \mathrm{MgCl}$, and 100 $\mathrm{m} M \mathrm{NaCl}$ (for details, see Ref. 44). Alternatively, insect cells (SF9, Sphodoptera frugiperda ovary cells) are transfected with baculovirus vector (Bacmid) carrying the cloned DNA interest. Insect cells are cultured at $27^{\circ}$ in SF-900 II SFM medium (Life Technologies, Gaithersburg, MD) and harvested $96 \mathrm{hr}$ after infection by centrifugation at $1200 \mathrm{~g}$.

ii. The expression of native RK in COS-7 has been previously described. ${ }^{51}$ Several mutants in the autophosphorylation and isoprenylation regions are analyzed using RK in this expression system. ${ }^{51,42}$ Frequently, lovastatin and simvastatin are used to improve radiolabeling of the isoprenylation group when ${ }^{14} \mathrm{C}$-labeled mevalonolactone is used. Application of these hydroxymethyl-glutaryl-CoA reductase inhibitors suppresses the production of endogenous mevalonic acid; however, it may lead to changes in the ratio of isoprenyl groups incorporated into the protein. 49

\section{Sites of Phosphorylation on Rho}

Successes in the analysis of the phosphorylation sites depend on the isolation of phosphopeptides. Several classic chemical methods have been described for the analysis of phosphorylation sites; however, advances in mass spectrometry have revolutionized the field of protein chemistry. As these methods evolve rapidly, we will not focus on actual mass spectrometric techniques, but rather on the isolation of peptides and problems related with their purification. The reader is encouraged to consult with the previous publication, which describes in more detail the problems related to the analysis of the phosphorylation sites on Rho*.52 The following standard methods are used for the purpose of identifying phosphorylation sites.

i. Phosphorylation and proteolysis. Phosphorylation of Rho is carried out in ROS membrane suspensions containing Rho $(3 \mu M)$, ATP $(2.5 \mathrm{~m} M)$, $\left[\gamma_{-}{ }^{33} \mathrm{P}\right]$ ATP $(550,000 \mathrm{cpm} / \mathrm{nmol}$, DuPontNew England Nuclear, Boston, $\mathrm{MA}), \mathrm{MgCl}_{2}(3 \mathrm{mM})$, and $0.1 M$ potassium phosphate, $\mathrm{pH}$ 7.5. All manipulations with the samples are done under a dim red light employing a Kodak No. 1 safelight filter (transmittance $>560 \mathrm{~nm}$ ). Radiation from ${ }^{33} \mathrm{P}$ is lower energy and decays slower 
than ${ }^{32} \mathrm{P}$. Protection shields for samples containing low radioactivity may not be necessary. The disadvantage is that ${ }^{33} \mathrm{P}$ is more costly than ${ }^{32} \mathrm{P}$. Phosphorylation is initiated by illumination using a $150-\mathrm{W}$ lamp from a distance of $20 \mathrm{~cm}$ at $30^{\circ}$. After $1 \mathrm{hr}$, the mixture is centrifuged, the supernatant is removed, and the pellet is resuspended in $1 \mathrm{ml}$ of $10 \mathrm{mM} \mathrm{BTP}$, $\mathrm{pH} 7.5$, containing $0.1 \mathrm{M} \mathrm{NaCl}$ for proteolysis.

ii. Proteolysis of Rho with endoproteinase Asp-N. To isolate phosphopeptides, [ $\left.{ }^{33} \mathrm{P}\right]$ phosphoopsin $(4 \mathrm{mg} / \mathrm{ml}$ ) is digested with $2 \mu \mathrm{g}$ endoproteinase Asp-N (Boehringer Mannheim) overnight at room temperature. The progress of digestion is verified by SDS-PAGE (Fig. 5A). The reaction is terminated by adding $300 \mu \mathrm{l}$ of $\mathrm{CH}_{3} \mathrm{CN}$ and $10 \mu \mathrm{l}$ of $\mathrm{CH}_{3} \mathrm{COOH}$. Peptides are separated from the insoluble material by ultracetrifugation at $100,000 \mathrm{~g}$ for $10 \mathrm{~min}$. The peptides are purified on HPLC, digested further with trypsin, endoproteinase Glu-C, thermolysin, aminopeptidase, and carboxypeptidase, ${ }^{52}$ and the phosphopeptide is separated from unphosphorylated peptide on $\mathrm{Ga}^{3+}$-immobilized metal affinity chromatography (IMAC) 53 (Fig. 5B) as described later.

iii. $\mathrm{Ga}^{3+}-\mathrm{IMAC}^{53}$ of the peptide mixtures is performed to separate phosphorylated/ unphosphorylated peptides. Chelating Sepharose gel (1 ml; Pharmacia,\#17-0575-01) is packed into a Pasteur pipette plugged with glass wool. The gel is washed with $0.1 \% \mathrm{CH}_{3} \mathrm{COOH}$ and then charged with $1 \mathrm{ml}$ of $1.1 \mathrm{M} \mathrm{GaCl}_{3}$ (Alfa Aesar,\#35698). After the column is equilibrated, peptides are loaded on $\mathrm{Ga}^{3+}$-charged resin. Unbound peptides are removed by an exhaustive wash with $0.1 \% \mathrm{CH}_{3} \mathrm{COOH}$. ${ }^{33} \mathrm{P}$-labeled phosphopeptides are eluted with $1 M \mathrm{NH}_{4} \mathrm{OH}$.

iv. HPLC of C-terminal phosphopeptides (Fig. 5B). The $\mathrm{Ga}^{3+}$-IMAC-purified phosphopeptides are injected onto a $\mathrm{C}_{18}$ HPLC column $(4.6 \times 150 \mathrm{~mm}$, Hewlett Packard XDB$\mathrm{C}_{18}$ ). Peptides are eluted employing a linear gradient from 0 to $45 \% \mathrm{CH}_{3} \mathrm{CN}$ with $0.05 \%$ TFA for $30 \mathrm{~min}$ at a flow rate of $1 \mathrm{ml} / \mathrm{min}$. The absorbance at $220 \mathrm{~nm}$ is monitored, and a small aliquot $(2 \mu \mathrm{l})$ from each fraction is used for counting of ${ }^{33} \mathrm{P}$ activity. Fractions with the highest activity are dried down using a Speed-Vac and are subjected to MS analysis.

\section{Mass Spectrometric Analysis of Sites of Phosphorylation}

The analysis of the phosphorylation site is complicated because RK phosphorylates Rho* at different sites. ${ }^{54}$ In vitro, at least two to four phosphates are incorporated per Rho*, due to the RK mechanism ${ }^{4}$ and the high abundance of Ser and Thr residues at the phosphorylation site at the C-terminal region of Rho. Dr. J. Buczylko made the important finding that Rho is cleaved specifically and uniquely at the $\mathrm{C}$ terminus by endoproteinase Asp- $\mathrm{C}^{40}$ (Fig. 5). Soluble peptide could be isolated and analyzed easily by further digestion with other proteolytic enzymes. ${ }^{44,52,54}$ Phosphorylation may prevent some proteolytic cleavages, helping in the identification of phosphopeptide. ${ }^{54,52}$ We developed complementary methods to isolate phospho-peptides using HPLC and heptafluorobutyric acid as a counter ion. ${ }^{7,55}$ In the presence of this acid, we have been able to separate monophosphorylated peptides of Rho into separate pools depending on the position of phosphorylation site.

Analysis of the phosphorylation peptides directly by mass spectrometry, for example, after purification using $\mathrm{Ga}^{3+}$-IMAC as described earlier (Fig. 5), could be difficult to interpret. Each 19 amino acid-long peptide phosphorylated at different positions produces a set of $\mathrm{b}$ and $\mathrm{y}$ ions that differ only in one to three ions. Two examples of ions from monophosphorylated peptide at different positions and nonphosphorylated peptide are shown in Fig. 6. Furthermore, many phosphorylated ions that are formed with low yields, undergo dephosphorylation and elimination reactions, and form complexes with $\mathrm{K}^{+}, \mathrm{Na}^{+}$, and $\mathrm{Ca}^{2+}$, introducing further heterogeneity. This makes these mass spectrometry techniques, used in published regimes, not suitable for quantitative analysis as discussed previously. 52 To obtain reliable information on the relative distribution of phosphate groups between different sites, radioactive methods are 
the most favorable in vitro and spectroscopic (optical) methods, in conjunction with the separation of phosphorylated peptides into individual species and mass spectrometry, are most suitable for the analysis in vivo. ${ }^{7}$

The primary sequences of phosphopeptides are confirmed by electrospray ionization mass spectrometry using a Bruker/Hewlett Packard Esquire LC iontrap HPLC/mass spectrometry at the resolution $( \pm 1 \mathrm{amu}$ at $14 \mathrm{kDa}$ ). The mass spectrometer is configured in direct injection mode, with nubulizer nitrogen at $20 \mathrm{psi}$, drying nitrogen at $10 \mathrm{liter} / \mathrm{min}$ and $300^{\circ}$, capillary and plate voltages at -4000 and -3500 , respectively (positive mode), and 3500 and 3000 , respectively (negative mode), mass scan range at 80-3000 amu, and the ion charge control (automatic gain control) activated with the target set at 15,000.

\section{Measuring Techniques for Binding Assays of RK to Rho}

Several methods were developed or modified to investigate the interaction of RK and Rho*. The most informative are light-scattering measurements and spectroscopic techniques (Fig. 7). These are complementary methods, also used successfully to study Rho* and $\mathrm{G}_{\mathrm{t}}$ interaction.

i. Light scattering. Light-scattering changes are measured in a setup similar to the one described previously. ${ }^{56}$ The measuring wavelength had to be chosen in the near infrared to avoid interference by both absorption changes and bleaching of Rho. The technique employs a continuous 840-nm incident light beam from a light-emitting diode (Hitachi HLP 60R). The scattered light is collected by two Fresnel lenses and is focused on a solid-state photodetector (Centronics OSD 100 5-T). Using different ring diaphragrams positioned between the Fresnel lenses, the scattering angle $\theta$ is selected, in the standard configuration $\theta=16 \pm 2^{\circ}$. LS signals are recorded with a 1- to 50-msec dwell time of the A/D converter (Nicolet 400); the cutoff frequency is routinely set to 0.2 of the dwell time. All measurements are performed in $10-\mathrm{mm}$ path cuvettes, in a final volume of $300 \mu$ l. LS signals are induced by flash photolysis of Rho with a green flash $(500 \pm 20 \mathrm{~nm})$, attenuated by appropriate neural density filters.

The LS-binding signal (see Fig. 7A) is interpreted as a gain of protein mass bound to the disk membranes and the LS dissociation signal (see Fig. 7B) as a loss of protein mass from the disk vesicle. A theoretical background for LS methods and the quantitative analysis for the binding and dissociation signal are published elsewhere. ${ }^{6}$

ii. Spectrophotometry. Formation of the photoproduct metarhodopsin II (Meta II, $\lambda_{\max }=380$ $\mathrm{nm}$ ) is assayed according to the two-wavelength technique. ${ }^{57}$ This technique minimizes scattering artifacts by comparing the flash-induced changes in the absorbance at 380 and 417 $\mathrm{nm}$. The absorbance change at $417 \mathrm{~nm}$ (Meta I isosbestic to Meta II) serves as a reference for determining the level of Meta II. The measurements are made by using a two-wavelength spectrophotometer (UV 300, Shimadzu Scientific Instruments, Inc., Japan; 2-nm slit) equipped with thermostated cuvettes (2-nm path), temperature regulated (Circulator G/D8, Haake $\mathrm{GmbH}$, Karlsruhe, Germany), and green photoflash (filtered to $500 \pm 20 \mathrm{~nm}$ ). The sample is placed next to the photomultiplier, and the temperature is measured with a thermistor (GR 2105, Peltron GmbH, Fürth, Germany). Flash artifacts are avoided using the differential "Spulse" output of the spectrophotometer for triggering the flash at the beginning of a voltagefree period of photomultiplier, which is additionally protected with a blue-green glass filter (BG 24, 2 mm, Schott, Mainz, Germany).

When Rho*, in its native disk membrane, is cooled to temperatures at which the equilibrium is on the Meta I side (below $5^{\circ}$ and $\mathrm{pH} 8.0$ ), ${ }^{58}$ binding of protein to Meta II causes an increase of Meta II (extra-Meta II, Fig. 7C). This so-called extra Meta II provides a kinetic and stoichiometric measure for the complex between Rho* and the interactive proteins. ${ }^{59}$ In both 
methods, the flash intensity is quantified by the amount of Rho* and is expressed in terms of the mole fraction of Rho* $(\mathrm{R} * / \mathrm{R})$.

\section{Comments}

Surprisingly, competition with $G_{t}$ for the active receptor [evident from the slowing of $G_{t}$ activation (Fig. 7B) and from reduced extra MII (Fig. 7C)] occurs with RK in the absence of ATP and phosphorylation. This argues for a direct competition of RK with $\mathrm{G}_{t}$, which is independent of the second substrate, the enzymatic function of ATP and RK, presumably due to direct steric hindrance by the bound protein (Fig. 8). Rho* shut off by binding of RK (in the absence of phosphorylation) fits to models of photoreceptor saturation, ${ }^{60}$ but does not seem to express itself in the single quantum regime. ${ }^{61}$ Note that in the parathyroid hormone receptor/ inositol phosphate pathway, $\mathrm{G}$ protein-coupled receptor kinases can inhibit receptor signaling under nonphosphorylating conditions. ${ }^{62}$

\section{Human Disease and Mutation in RK Gene}

The RK locus has been assigned to chromosome 13 band $\mathrm{q} 34^{63}$, and the RK gene is composed of seven exons. Mutation in RK is associated with human conditions that cause desensitization of the visual system after an intense illumination for a longer period of time than wild type. This condition, called Oguchi disease, is a recessively inherited form of stationary night blindness due to the malfunction of RK in Rho quenching*.64,65 Many cases are found to be homozygous for mutations of RK leading to a nonfunctional protein. From studies of patients with Oguchi disease, we learned that the role of RK in rods would be to accelerate the inactivation of Rho*, that in concert with regeneration, leads to the normal rate of recovery of sensitivity. Cones may rely mainly on regeneration for the inactivation of photolyzed visual pigments, but RK also contributes to cone recovery. Further analysis of other patients could be carried out using the genetical and physical approaches as published. 64,65

\section{Other Methods}

i. Sodium dodecyl sulfate-polyacrylamide gel electrophoresis. SDS-PAGE is performed using $10 \%$ SDS-PAGE gel in a Hoefer (San Francisco, Ca) minigel apparatus. The gel is stained with Coomassie brilliant blue R-250 and destained with $50 \%$ (v/v) $\mathrm{CH}_{3} \mathrm{OH}$ and $7 \%(\mathrm{v} / \mathrm{v}$ ) $\mathrm{CH}_{3} \mathrm{COOH}$.

ii. Immunoblotting. The SDS-PAGE gel is placed in transfer buffer (10 $\mathrm{m} M$ BTP, $\mathrm{pH} 8.4)$ containing $10 \% \mathrm{CH}_{3} \mathrm{OH}$ for $10 \mathrm{~min}$. Electroblotting onto Immobilon-P (Milipore, Bedford, $\mathrm{MA}$ ) is performed at $90 \mathrm{~V}$ for $1 \mathrm{hr}$ at $4^{\circ}$. After completion of the transfer, the membrane is blocked with 3\% gelatin in $20 \mathrm{~m} M$ Tris- $\mathrm{HCl}, \mathrm{pH} 8.0$, containing $150 \mathrm{mM} \mathrm{NaCl}$ and $0.05 \%$ Tween 20, and is incubated with monoclonal antibodies (G8) at dilution $1: 5000 \mathrm{for} 1 \mathrm{hr}$ at room temperature. Secondary antibodies conjugated with alkaline phosphatase (Promega, Madison, WI) are used at $1: 5000$. Antibody binding is detected using 5-bromo-4-chloro-3indolyl phosphate and nitro blue tetrazolium.

\section{Conclusions}

RK is an important enzyme of phototransduction, and its role in human physiology is exquisitely characterized. ${ }^{65}$ Many techniques were developed to isolate the enzyme, assay it, and characterize specific interactions with Rho*. Several posttranslational modifications were characterized. With these basic techniques in hand, mechanistical, kinetic, and structural questions can be asked. Toward this goal, structural information on RK, Rho, and Rho* is needed. 


\section{Acknowledgments}

This research was supported by NIH Grants EY08061 (KP), a National Science Foundation Chemistry Instrumentation Grant (CHE 9807748 to U.W.), and Deutsche Forschungsgemeinschaft Grant Sfb 449 (KPH), and the Fonds der Chemischen industrie (KPH), an unrestricted grant from Research to Prevent Blindness, Inc. (RPB), New York, to the Department of Ophthalmology at the University of Washington, and the E.K. Bishop Foundation. We thank Preston Van Hooser for help during the course of this study, Dr. Rosalie Crouch for synthetic retinoids, and Joshua McBee for critical reading of the manuscript.

\section{References}

1. Polans A, Baehr W, Palczewski K. TINS 1996;19:547. [PubMed: 8961484]

2. Koutalos Y, Yau KW. TINS 1996;19:73. [PubMed: 8820871]

3. Lagnado L, Baylor D. Neuron 1992;8:995. [PubMed: 1377000]

4. Palczewski K. Eur. J. Biochem 1997;248:261. [PubMed: 9346277]

5. Kroog GS, Jian XY, Chen L, Northup JK, Battey JF. J. Biol. Chem 1999;274:36700. [PubMed: 10593975]

6. Heck M, Pulvermüller A, Hofmann KP. Methods Enzymol 2000;315:329. [PubMed: 10736711]

7. Ohguro H, Van Hooser JP, Milam AH, Palczewski K. J. Biol. Chem 1995;270:14259. [PubMed: 7782279]

8. Bennett N, Sitaramayya A. Biochemistry 1988;27:1710. [PubMed: 3365420]

9. Palczewski K, Buczyłko J, Ohguro H, Annan RS, Carr SA, Crabb JW, Kaplan MW, Johnson RS, Walsh KA. Protein Sci 1994;3:314. [PubMed: 8003967]

10. Smith WC, Milam AH, Dugger D, Arendt A, Hargrave PA, Palczewski K. J. Biol. Chem 1994;269:15407. [PubMed: 7515057]

11. Palczewski K, Smith WC. Exp. Eye Res 1996;63:599. [PubMed: 8994364]

12. Palczewski K, Hargrave PA, McDowell JH, Ingebritsen TS. Biochemistry 1989;28:415. [PubMed: 2540796]

13. Fowles C, Akhtar M, Cohen P. Biochemistry 1989;28:9385. [PubMed: 2558719]

14. Inglese J, Freedman NJ, Koch WJ, Lefkowitz RJ. J. Biol. Chem 1993;268:23735. [PubMed: 8226899]

15. Haga T, Haga K, Kameyama K. J. Neurochem 1994;63:400. [PubMed: 8035170]

16. Premont RT, Inglese J, Lefkowitz RJ. FASEB J 1995;9:175. [PubMed: 7781920]

17. Lohse MJ, Bluml K, Danner S, Krasel C. Biochem. Soc. Trans 1996;24:975. [PubMed: 8968495]

18. Ferguson SSG, Barak LS, Zhang J, Caron MG. Can. J. Physiol. Pharmacol 1996;74:1095. [PubMed: 9022829]

19. Chuang TT, Iacovelli L, Sallese M, DeBlasi A. TIPS 1996;17:416. [PubMed: 8990958]

20. Pitcher JA, Freedman NJ, Lefkowitz RJ. Annu. Rev. Biochem 1998;67:653. [PubMed: 9759500]

21. Palczewski K, Benovic JL. TIBS 1991;16:387. [PubMed: 1664548]

22. Zhao XY, Haeseleer F, Fariss RN, Huang JN, Baehr W, Milam AH, Palczewski K. Visual Neurosci 1997; 14:225.

23. Pulvermüller A, Palczewski K, Hofmann KP. Biochemistry 1993;32:14082. [PubMed: 8260489]

24. Buczyłko J, Saari JC, Crouch RK, Palczewski K. J. Biol. Chem 1996;271:20621. [PubMed: 8702809]

25. Palczewski K, Buczyłko J, Lebioda L, Crabb JW, Polans AS. J. Biol. Chem 1993;268:6004. [PubMed: 8383684]

26. Papermaster DS. Methods Enzymol 1982;81:48. [PubMed: 6212746]

27. Palczewski K, McDowell JH, Hargrave PA. J. Biol. Chem 1988;263:14067. [PubMed: 2844754]

28. Palczewski K, Arendt A, McDowell JH, Hargrave PA. Biochemistry 1989;28:8764. [PubMed: 2605220]

29. Palczewski K, McDowell JH, Hargrave PA. Biochemistry 1988;27:2306. [PubMed: 3382623]

30. Palczewski K. Methods Neurosci 1993;15:217.

31. Buczyłko J, Gutmann C, Palczewski K. Proc. Natl. Acad. Sci. U.S.A 1991;88:2568. [PubMed: 2006192] 
32. Onorato JJ, Palczewski K, Regan JW, Caron MG, Lefkowitz RJ, Benovic JL. Biochemistry 1991;30:5118. [PubMed: 1645191]

33. Shichi H, Somers RL. J. Biol. Chem 1978;253:7040. [PubMed: 690139]

34. McDowell JH. Methods Neurosci 1993;15:123.

35. Palczewski K, Kahn N, Hargrave PA. Biochemistry 1990;29:6276. [PubMed: 2207073]

36. Lebioda L, Hargrave PA, Palczewski K. FEBS Lett 1990;266:102. [PubMed: 2365059]

37. Sachs K, Maretzki D, Meyer CK, Hofmann KP. J. Biol. Chem 2000;275:6189. [PubMed: 10692411]

38. Palczewski K, Buczyłko J, Van Hooser JP, Carr SA, Huddleston MJ, Crabb JW. J. Biol. Chem 1992;267:18991. [PubMed: 1527025]

39. Fowles C, Sharma R, Akhtar M. FEBS Lett 1988;238:56.

40. Palczewski K, Buczyłko J, Kaplan MW, Polans AS, Crabb JW. J. Biol. Chem 1991;266:12949. [PubMed: 2071581]

41. Lorenz W, Inglese J, Palczewski K, Onorato JJ, Caron MG, Lefkowitz RJ. Proc. Natl. Acad. Sci. U.S.A 1991;88:8715. [PubMed: 1656454]

42. Palczewski K, Ohguro H, Premont RT, Inglese J. J. Biol. Chem 1995;270:15294. [PubMed: 7797516]

43. Zhao XY, Yokoyama K, Whitten ME, Huang J, Gelb MH, Palczewski K. FEBS Lett 1999;454:115. [PubMed: 10413107]

44. Ohguro H, Rudnicka-Nawrot M, Buczyłko J, Zhao XY, Taylor JA, Walsh KA, Palczewski K. J. Biol. Chem 1996;271:5215. [PubMed: 8617805]

45. Palczewski K, Carruth ME, Adamus G, McDowell JH, Hargrave PA. Vision Res 1990;30:1129. [PubMed: 2402884]

46. Chen CK, Inglese J, Lefkowitz RJ, Hurley JB. J. Biol. Chem 1995;270:18060. [PubMed: 7629115]

47. Zhao XY, Huang J, Khani SC, Palczewski K. J. Biol. Chem 1998;273:5124. [PubMed: 9478965]

48. Cha KW, Bruel C, Inglese J, Khorana HG. Proc. Natl. Acad. Sci. U.S.A 1997;94:10577. [PubMed: 9380677]

49. Whitten ME, Yokoyama K, Schieltz D, Ghomashich F, Kam D, Yates JR, Palczewski K, Gelb MH. Methods Enzymol 2000;316:436. [PubMed: 10800693]

50. Inglese J, Glickman JF, Lorenz W, Caron MG, Lefkowitz RJ. J. Biol. Chem 1992;267:1422. [PubMed: 1730692]

51. Inglese J, Koch WJ, Caron MG, Lefkowitz RJ. Nature 1992;359:147. [PubMed: 1522899]

52. Palczewski, K.; Van Hooser, JP.; Ohguro, H. Regulation of G Protein-Coupled Receptor Function and Expression. Benovic, JL., editor. Wiley-Liss; New York: 2000. p. 69

53. Posewitz MC, Tempst P. Anal. Chem 1999;71:2883. [PubMed: 10424175]

54. Ohguro H, Palczewski K, Ericsson LH, Walsh KA, Johnson RS. Biochemistry 1993;32:5718.

[PubMed: 8504090]

55. Ohguro H, Palczewski K. FEBS Lett 1995;368:452. [PubMed: 7635197]

56. Hofmann KP, Schleicher A, Emeis D, Reichert J. Biophysics Struct. Mech 1981;8:67.

57. Schleicher A, Kühn H, Hofmann KP. Biochemistry 1989;28:1770. [PubMed: 2719933]

58. Parkes JH, Liebman PA. Biochemistry 1984;23:5054. [PubMed: 6498176]

59. Hofmann KP. Biochim. Biophys. Acta 1985;810:278. [PubMed: 3933561]

60. Laitko U, Hofmann KP. Biophys. J 1998;74:803. [PubMed: 9533693]

61. Chen CK, Burns ME, Spencer M, Niemi GA, Chen J, Hurley JB, Baylor DA, Simon MI. Proc. Natl. Acad. Sci. U.S.A 1999;96:3718. [PubMed: 10097103]

62. Dicker F, Quitterer U, Winstel R, Honold K, Lohse MJ. Proc. Natl. Acad. Sci. U.S.A 1999;96:5476. [PubMed: 10318908]

63. Khani SC, Abitbol M, Yamamoto S, Maravic-Magovcevic I, Dryja TP. Genomics 1996;35:517. [PubMed: 8812486]

64. Yamamoto S, Sippel KC, Berson EL, Dryja TP. Nature Genet 1997;15:175. [PubMed: 9020843]

65. Cideciyan AV, Zhao XY, Nielsen L, Khani SC, Jacobson SG, Palczewski K. Proc. Natl. Acad. Sci. U.S.A 1998;95:328. [PubMed: 9419375] 
Fig. 1.

(A) Inactivation of the signaling state of Rho (Rho* or $\mathrm{R}^{*}$ ) by phosphorylation and binding of Arr. $R$ represents the dark state, inactive form of $R h o, G_{t}$, transducin; and $p^{44}$ is a short splice version of Arr. (B) Phylogenetic tree of GRKs. The tree was built with a bootstrap analysis of neighbor-joining distance using PAUPSearch in GCG (University of Wisconsin-Genetics Computer Group). The accession numbers are GRK1, Q15835; GRK2, X61157; GRK3, P35626; GRK4, P32298; GRK5, P34947; GRK6, P43250; ground squirrel GRK7, AF063016. 


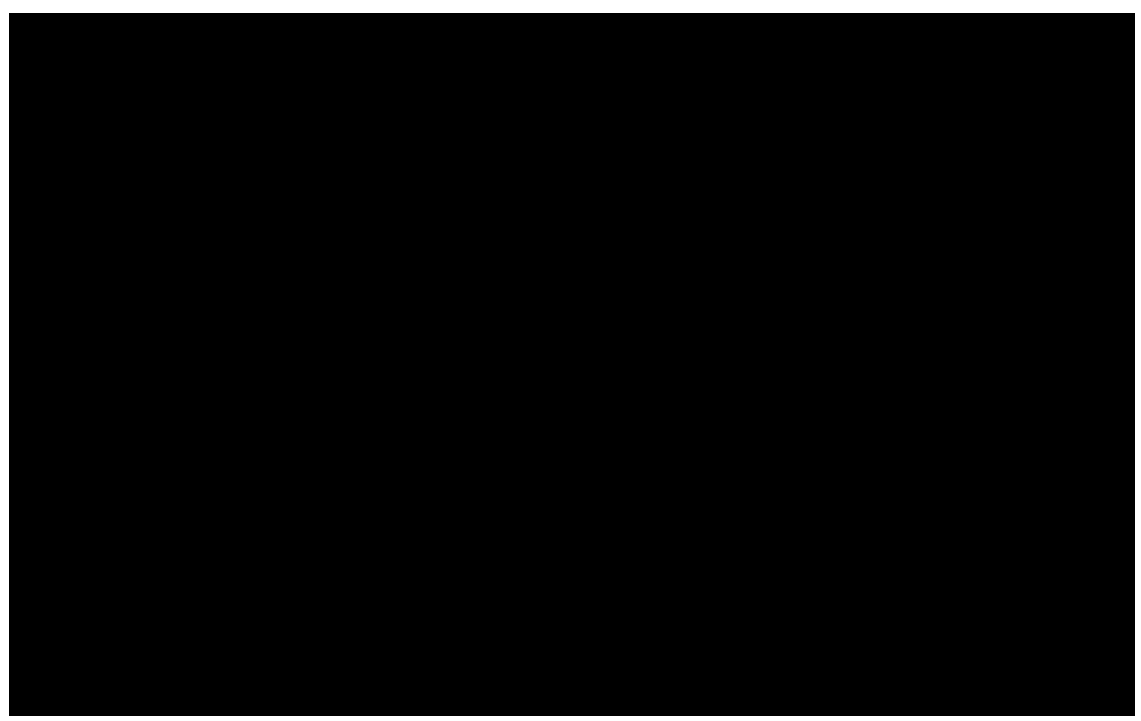

Fig. 2.

Assay RK activity. Time (A) and dose (B) dependence of RK activity. RK was partially purified from SF9 cells. 


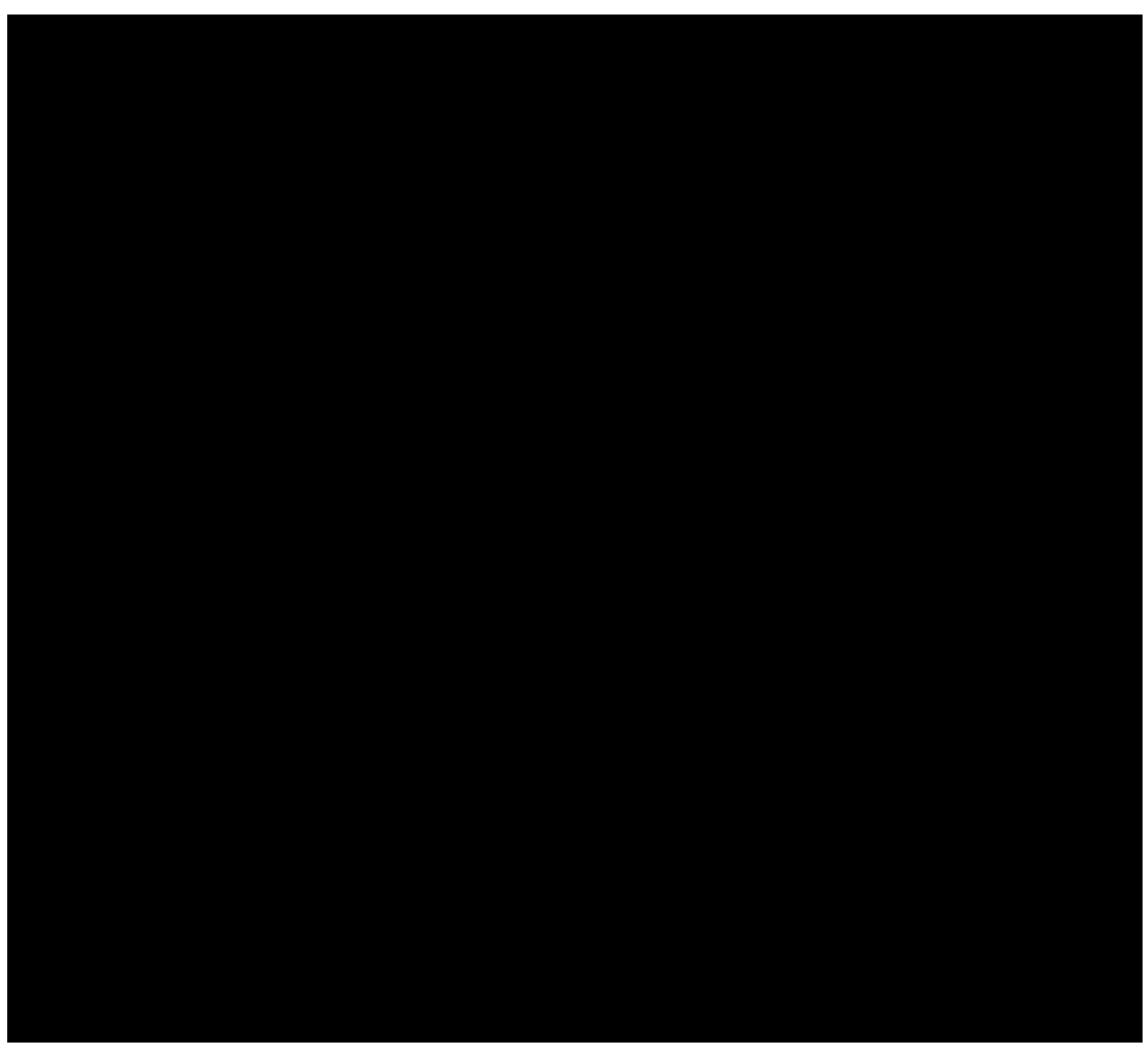

Fig. 3.

Molecular rules of opsin activation: phosphorylation of opsin in the presence of all-trans-retinal analogs of different lengths and their derivatives with blocked aldehyde groups. (A) Phosphorylation of opsin is carried out in the presence of all-trans-retinal, all-trans-C17 aldehyde, all-trans-C15 aldehyde, trans-C12 aldehyde, or their oximes generated with $\mathrm{NH}_{2} \mathrm{OH}, \mathrm{NH}_{2} \mathrm{OCH}_{3}$, or $\mathrm{NH}_{2} \mathrm{OCH}_{2} \mathrm{CH}_{3}$ (8 M excess over $30 \mu M$ opsin). The solid horizontal line represents opsin activity. (B) Activity expressed as percentage of maximum phosphorylation for each of the aldehydes (marked as a continuous line). The phosphorylation reaction is carried out in $30 \mathrm{~m} M \mathrm{BTP}, \mathrm{pH} 6.5$, containing $3 \mathrm{~m} M \mathrm{MgCl}_{2}$. Data are reproduced with permission from the American Society for Biochemistry and Molecular Biology, Inc. [J. Buczyłko, J. C. Saari, R. K. Crouch, and K. Palczewski, J. Biol. Chem. 271, 20621 (1996)]. (C) Structures of all-trans-retinal, all-trans-C17 aldehyde, all-trans-C15 aldehyde, trans-C12 aldehyde. 


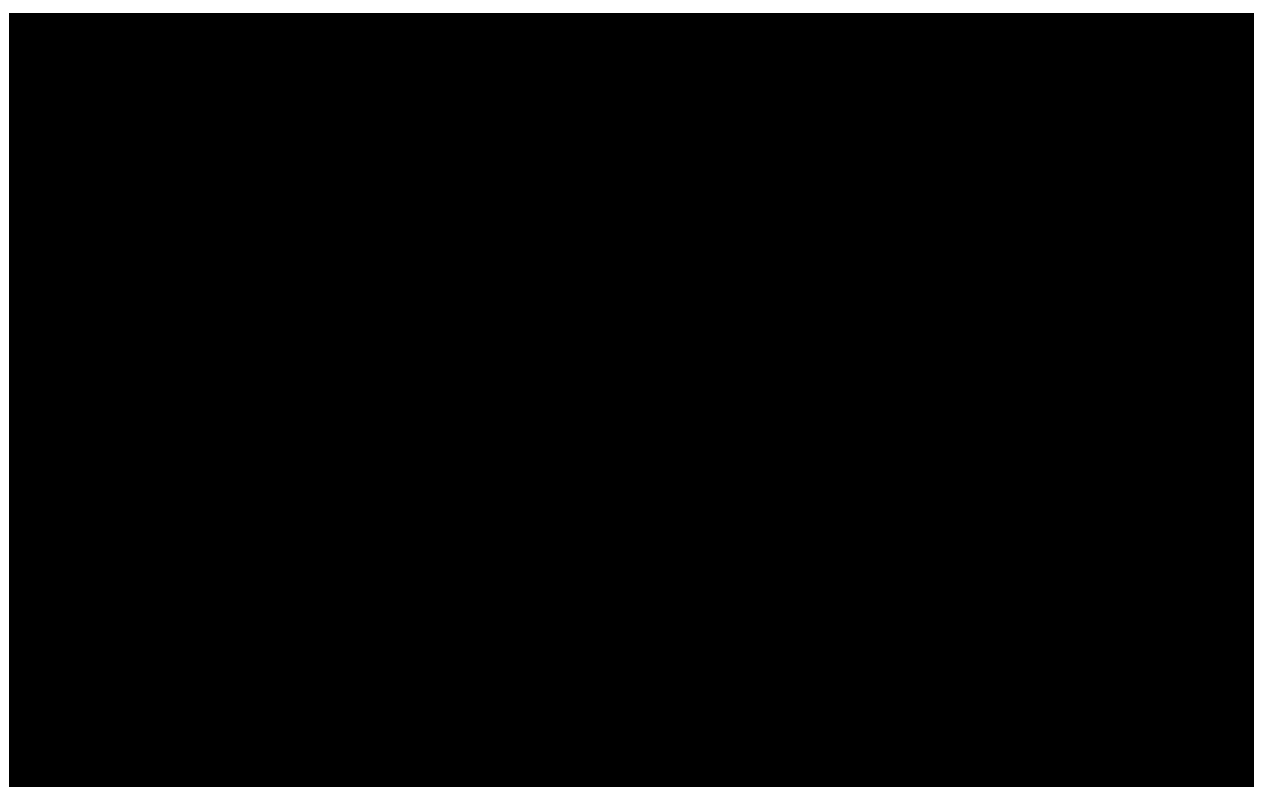

Fig. 4.

Domain structure of RK, purification, and immunoblotting. (A) The N-terminal domain ( 180 amino acids) may be involved in the interaction with Rho*. ${ }^{25}$ The ATP-specific, catalytic domain is found in the middle of the sequence. The C-terminal domain is the site of autophosphorylation on Ser and Thr residues within the sequence FSTVKGV and is also modified by isoprenylation/carboxymethylation. This autophosphorylation changes the affinity for heparin and is used to purify RK. Bound RK is autophosphorylated on the heparinSepharose column and eluted at lower salt than is required for the elution of unphosphorylated kinase (see text). (B) Schematic representation of the elution profile for autophosphorylated and dephosphorylated RK from heparin-Sepharose column. At a high salt concentration ( $\sim 150$ $\mathrm{m} M \mathrm{NaCl}$ ), unphosphorylated $\mathrm{RK}$ is bound to the resin and is eluted specifically with ATP/ $\mathrm{Mg}^{2+}$ as a result of autophosphorylation. (C) Mobility shift of RK dephosphorylated by PrP2A (lane a) and autophosphorylated in the presence of ATP (lane b). Multiple forms of autophosphorylated RK are visualized by Western blotting of isolated bovine ROS (lane c) probed with monoclonal antibody G8. 


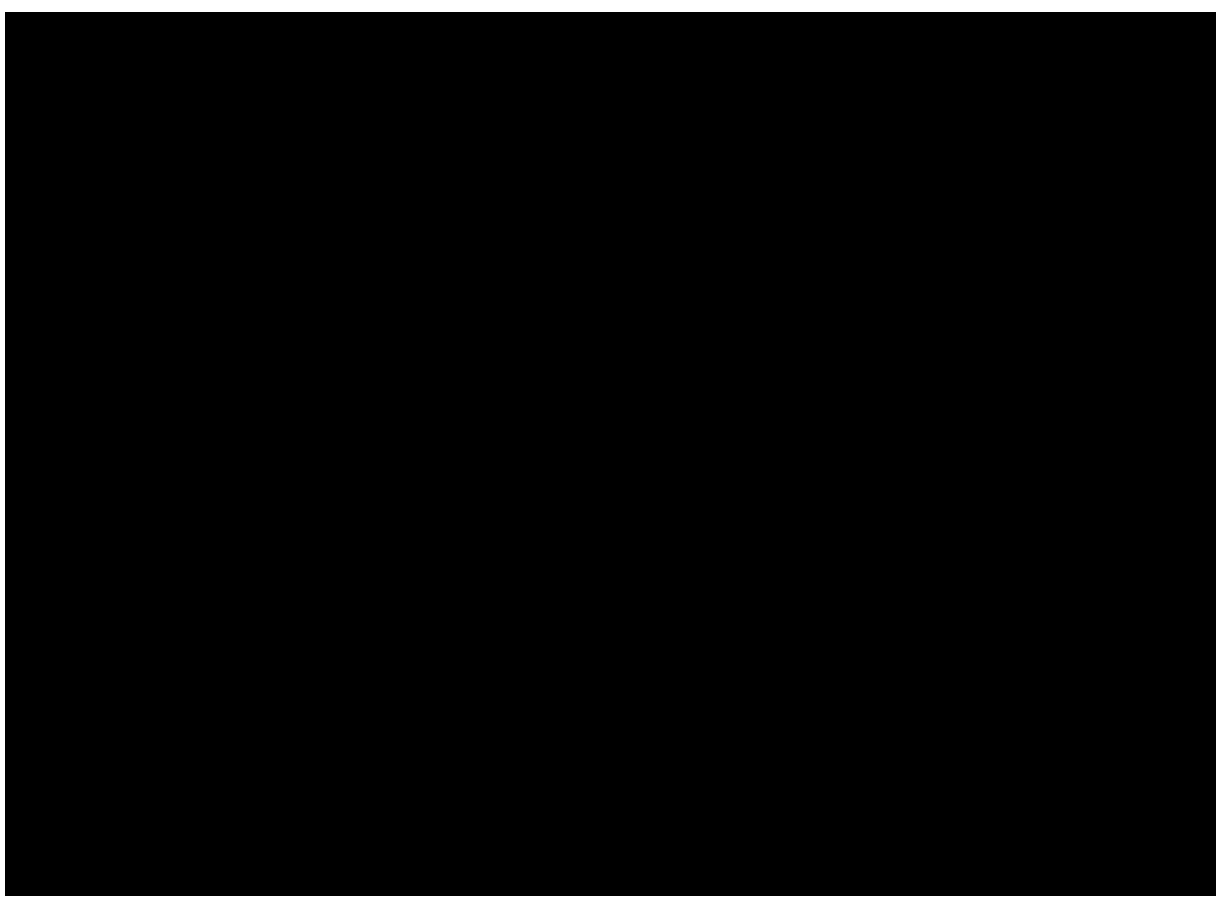

Fig. 5.

Proteolysis of Rho and isolation of the C-terminal phosphorylated peptide. (A) SDS-PAGE of standards (lane a in $\mathrm{kDa}),{ }^{33} \mathrm{P}$-labeled Rho (lane $\mathrm{b}$ ), and Rho digested with endoproteinase Asp-N (lane c). (Rho) $)_{2}$ and $\left({ }^{329} \mathrm{G}-\mathrm{Rho}\right)_{2}$ represent dimers formed during sample preparation. The proteolytic-insoluble nonradioactive ${ }^{329} \mathrm{G}$-Rho fragment is separated from the soluble Cterminal ${ }^{33} \mathrm{P}$ peptide by pelleting membranes. (B) The C-terminal peptide is initially purified on $\mathrm{Ga}^{3+}$-IMAC and finally on a $\mathrm{C}_{18}$ column using HPLC. 
Fig. 6.

Predicated pattern of ions formed from the C-terminal fragment of Rho during mass spectrometrical analysis. The $\mathrm{b}$ series and y series of ions formed from (A, B) DDDEASTTVSKTETSQVAPA peptide (C) from unphosphorylated monophosphorylated peptides at Ser-334, or (D) from unphosphorylated monophosphorylated peptides Ser-338. 


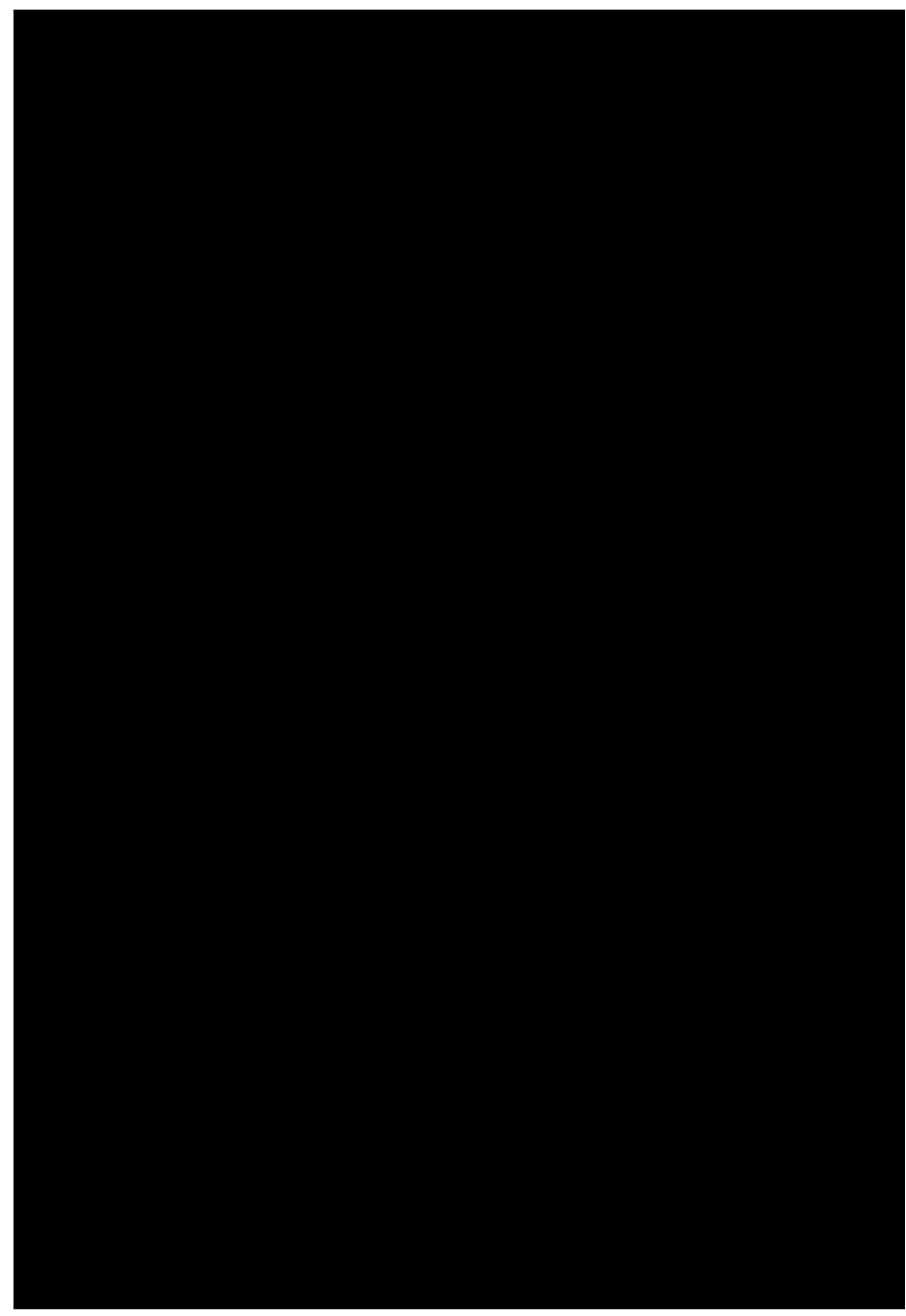

Fig. 7.

(A) Flash-induced light-scattering binding signals measured on suspensions of washed disk membranes reconstituted with purified RK. Binding of the proteins is studied using disk membranes containing either unphosphorylated (Rho, upper trace) or (pre)phosphorylated Rho (P-Rho, middle trace), respectively. In the lower trace, autophosphorylated RK (P-RK) is used with Rho. All signals were corrected for control signals measured without added kinase. 23 Measuring conditions: $3 \mu M$ Rho and $1 \mu M$ RK. The flash illuminated $35 \%$ of Rho, the total volume is $300 \mu \mathrm{l}$, and the cuvette path length is $10 \mathrm{~mm}$. (B) Inhibition of $\mathrm{G}_{\mathrm{t}}$ activation by $\mathrm{RK}$. Dissociation signals induced by flash of intensity $R * / R=9 \times 10^{-3}$ in the presence of $G_{t}$ and GTP. From the lower to the upper trace the amount of RK is increased. Measuring conditions: $3 \mu M$ Rho (washed membranes), $0.4 \mu M$ purified $\mathrm{G}_{\mathrm{t}}$, and $1 \mathrm{~m} M \mathrm{GTP}$. (C) Inhibition of $\mathrm{G}_{\mathrm{t}^{-}}$ dependent Meta II stabilization by RK. Upper trace, Meta II formation in the presence of 1 $\mu M \mathrm{G}_{\mathrm{t}}$; middle trace, suppression of Meta II formed with $1 \mu M \mathrm{G}_{\mathrm{t}}$ by the addition of $1 \mu M \mathrm{RK}$; lower trace, control with Rho alone. Measuring conditions: $2 \mu M$ Rho in $100 \mathrm{mM}$ BTP, pH 8.0, containing $90 \mu M$ GDP; $4^{\circ}$; flash excitation, 20\%; cuvette path length, $2 \mathrm{~mm}$. 


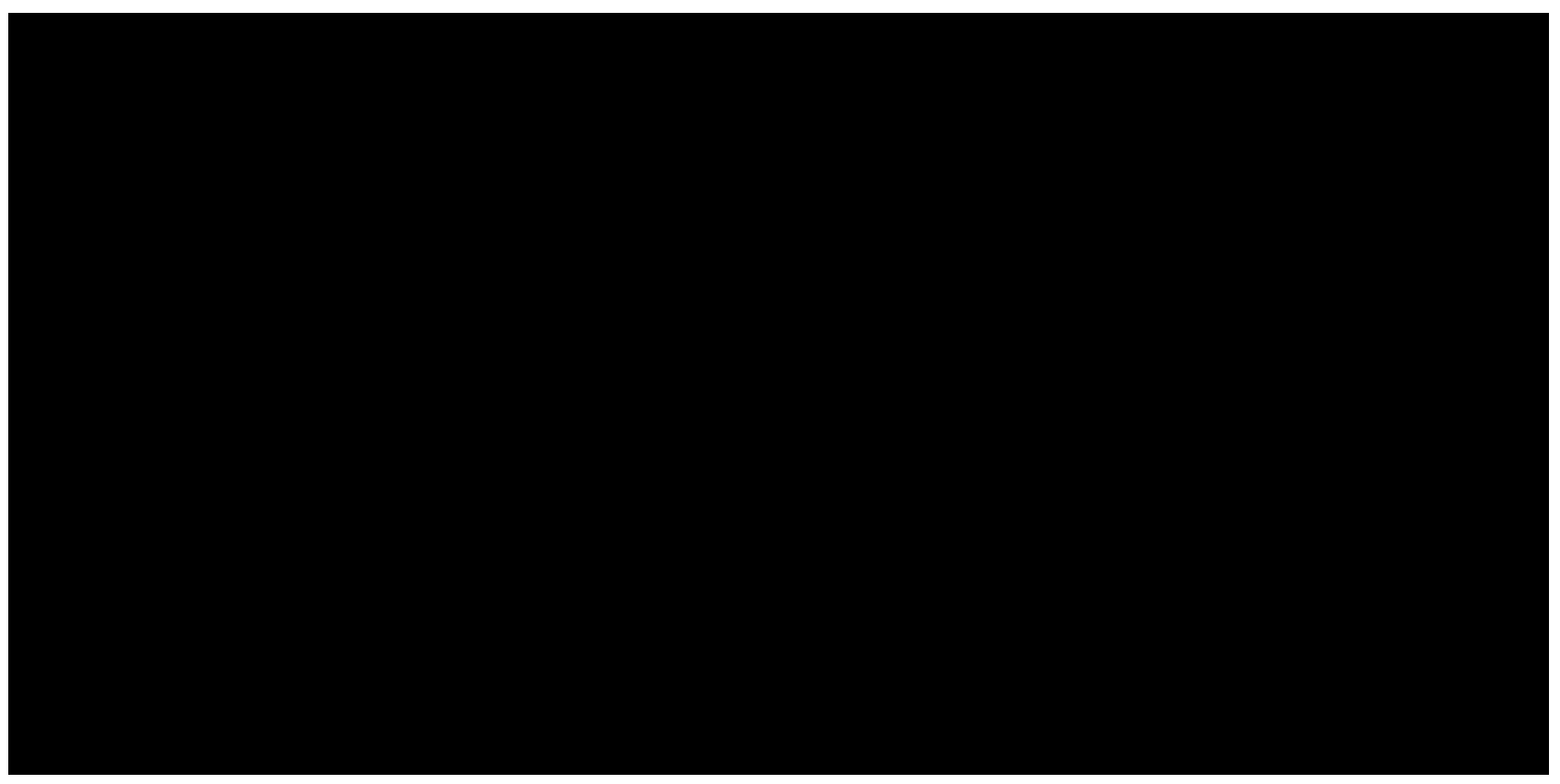

Fig. 8.

Model of RK binding to membranes. (A) Binding of RK to Rho*. The model illustrates the direct binding of $\mathrm{RK}$ to light $\mathrm{R}^{*}$. For simplification, this model does not distinguish between the different Meta states of Rho*. (B) Activation of $\mathrm{G}_{t}$ and its inhibition by RK. In the presence of GTP, at the preformed complex between $R^{*}$ and $G_{t}$, GTP binds to the $G_{t \alpha}$ subunit followed by the dissociation of $G_{t \alpha}$ from both $R^{*}$ and $G_{t \beta \gamma}$. This model shows that activation of $G_{t}$ by $\mathrm{R}^{*}$ is accompanied in vitro by a rapid release of the $\mathrm{G}_{\mathrm{t}}$ subunits from the disk surface and that this release can be inhibited by the direct binding of RK to $\mathrm{R}^{*}$. It is important to note that only the fraction of $G_{t}$ present on the membrane at the time of the flash is monitored in the dissociation signal. (C) $\mathrm{G}_{\mathrm{t}}$-dependent MII stabilization and its inhibition by RK. As illustrated in this model, binding of $\mathrm{G}_{\mathrm{t}}$ stabilizes only metarhodopsin II (Meta II, $\lambda_{\max }=380 \mathrm{~nm}$ ) at the cost of other, noninteractive and spectrophotometrically different forms of Rho*, e.g.,

metarhodopsin I (Meta I, $\lambda_{\max }=480 \mathrm{~nm}$ ). RK can bind to Meta I and Meta II. When $\mathrm{G}_{\mathrm{t}}$ and RK are present simultaneously, RK inhibits the complex formation between $R^{*}$ and $G_{t}$, resulting in the suppression of the extra-Meta II signal (see Fig. 7C). 